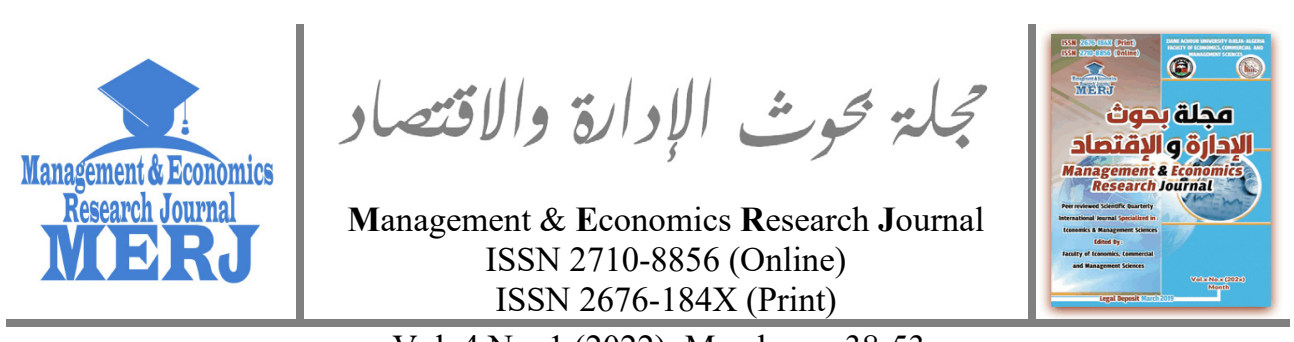

Vol. 4 No. 1 (2022): March, pp. 38-53

https://doi.org/10.48100/merj.2022.181

Check for updates

\title{
The Effect of Organizational Culture on Financial Performance: Based on Cameron and Quinn Model (CVF)
}

\author{
Ahmed K Elnagar ${ }^{1}$ (D), Ahmed Abdelkawi ${ }^{2}$, Ibrahim Elshaer ${ }^{3}$, Said Salama ${ }^{4}$ \\ ${ }^{1}$ Assistant Professor of Hospitality Management, Department of Administrative and \\ Financial Sciences and Techniques, Applied College, Taibah University, Medinah (Saudi \\ Arabia); Faculty of Tourism and Hotel Management, Suez Canal University (Egypt) \\ $\bowtie$ ahmed_karam@tourism.suez.edu.eg \\ ${ }^{2,3}$ Associate Professor of Hotel Management, Faculty of Tourism and Hotel Management, \\ Suez Canal University (Egypt) \\ ${ }^{2} \bowtie$ doctor ahmedhasan@yahoo.com, ${ }^{3} \bowtie$ elshaeribrahem@yahoo.com \\ ${ }^{4}$ Professor of Hotel Management, Faculty of Tourism and Hotel Management, Suez Canal \\ University (Egypt) \\ ssalama@tourism.suez.edu.eg
}

Received: 07-12-2021

Accepted: $01-02-2022$

Published online: 03-02-2022

\section{How to Cite:}

K Elnagar, A., Abdelkawi, A., Elshaer, I., \& Salama, S. (2022). The Effect of Organizational Culture on Financial Performance: Based on Cameron and Quinn Model (CVF). Management \& Economics Research Journal, 4(1), 38-53. https://doi.org/10.48100/merj.2022.181

\begin{abstract}
:
The research objective is to investigate the impact of organizational culture (OC) based on the Cameron and Quinn model (The Competing Value Framework) on financial performance (FP) in Egyptian hotels. The research used five dimensions (occupancy percentage, average room rate, RevPAR, average market share, and average revenue) to measure FP in hotels.
\end{abstract}

- Corresponding author: Department of Administrative and Financial Sciences and Techniques, Applied College, Taibah University, Medinah (Saudi Arabia); Faculty of Tourism and Hotel Management, Suez Canal University (Egypt).

[ $\square$ ahmed_karam@tourism.suez.edu.eg]

(C2022 the Author(s). This is an open-access article distributed under the terms of (CC BY-NC 4.0) which permits use, distribution and reproduction in any medium, provided the original work is properly cited and is not used for commercial purposes. 
K Elnagar, A.,

Abdelkawi, A., Elshaer,

I., \& Salama, S.
The Effect of Organizational Culture on Financial

Performance: Based on Cameron and Quinn Model (CVF)

Quantitative methods were used to achieve the research objective through the questionnaire. A total of 416 questionnaires were provided to general, executive, HR, and quality managers working in four five-star hotels in Sharm El Sheikh city 104 hotel in Egypt. The research used three main data analysis techniques: descriptive analysis, correlation, and multi-regression by SPSS V25. Empirical findings showed that OC positively affected the FP of hotels. The research recommends that hotels in Egypt to attention to the consolidation of OC types because of their positive impact on enhancing the FP of hotels. Hotels should also promote organizational values such as fairness, equality, teamwork, and employee cooperation and, in addition, enhance the interest in organizational beliefs such as the human element and job satisfaction to increase rewards and incentives.

Keywords: Organizational Culture, Financial Performance, Competing Value Framework (CVF), Egyptian Hotels.

JEL Codes: G32, G20, O16.

\section{Introduction}

Today, organizations, particularly hotels, strive for rapid growth, profitability, continuous improvement, long-term planning, and a dominant position in their global activities. Furthermore, today's firms operate in a constantly changing environment that is difficult to predict. Because of these issues, firms have spent significant time and money-making changes to achieve high performance. Indeed, in this age of change, achieving performance excellence through traditional management methods is impossible, and organizations are forced to adopt new managerial approaches to achieve financial performance (FP) (Nikpour, 2017; Elnagar \& Sayed, 2021). As a result, identifying the factors that influence FP is critical. In this regard, studies have revealed that the company's organizational culture (OC) is one factor that can impact FP. As a result, managers must understand how to leverage $\mathrm{OC}$ and treat it as an asset to provide FP. Managers who understand how OC provides FP can deliberate on which aspects of the culture to focus on (clan culture, adhocracy culture, market culture, and hierarchy culture) to improve FP (Denision \& Mishra, 1995; Amin et al., 2017).

Extensive research shows that $\mathrm{OC}$ has evolved from an organically emergent phenomenon to a flexible and manageable competitive asset and a strong predictor of performance (Denison \& Mishra, 1995). Further investigation into whether temporal factors mediate or moderate this unstudied process could have far-reaching implications for business and 
social contexts. Organizations that include OC theory and assessment in their strategic planning processes have shown enhanced effectiveness and improved results in market share, sales growth, profitability, innovation, employee engagement, and customer happiness. Regardless of the industry sector or country, organisations must be purposeful about establishing and maintaining a high-performing culture that links culture and financial performance in this era of global competition for products and services (Cameron \& Quinn, 2006).

This introduction provides an insight into the reasons (i.e., why this research deserves to be conducted). As a result, this article aims to look into the impact of OC on FP in the Egyptian hotel business.

\section{Literature review}

\subsection{Organizational culture concept}

Defining the term OC is difficult because it necessitates defining organization and culture. According to some, the definitions of culture can be divided into two categories: objective entity or a variable and metaphor (Brown, 1998; Alvesson \& Sveningsson, 2008). Culture is described by Schein (1990) on three levels to describe culture, including observable artefacts, values, and essential underlying assumptions. The work-hard and play-hard culture, process culture, bet-your company culture, and the toughguy and macho culture are among the four cultural types described by Deal \& Kennedy (1982).

Culture is a property of a human group of common significance possessed by a firm's members, which differs significantly from other firms (Robbins, 2005). Others have claimed that culture refers to a set of beliefs, values, attitudes, assumptions, expectations, and ways of behaviour shared among individuals of an organization (Kotter \& Heskett, 1992; Zeb et al., 2021).

Hofstede et al. (1990) proposed the following formulation to incorporate the many dimensions of OC: The organizational/corporate culture construct is (1) generally decided, (2) holistic, (3) linked in anthropological ideas, (4) socially built, (5) soft, and (6) challenging to modify. This definition incorporates aspects of OC relevant to other researchers' viewpoints. Firstly, culture can represent an organization's overall picture of its members' selfidentity (Robbins, 2005). Second, OC is shaped by long-term historical tradition, considered an unseen hand in public administration (Zeb et al., 2021). As a result, culture is difficult to modify; according to Helmke and Levitsky (2004), culture is viewed as an informal institution, and reform 
K Elnagar, A.,

Abdelkawi, A., Elshaer,

I., \& Salama, S.
The Effect of Organizational Culture on Financial

Performance: Based on Cameron and Quinn Model (CVF)

would be a protracted process. Third, culture is linked to social and anthropological regions, which can be read as (organizations have cultures or organizations are cultures) (Cameron \& Quinn, 2003).

As per the above, OC is a set of cultures such as clan culture, market culture, hierarchy culture, and adhocracy culture. OC contains behaviour patterns, beliefs, values, and work styles that form the identity of the hotel/firm, distinguish it from others, and improve and improve its performance.

Regarding OC characteristics, Collins and Porras (1994) state that OC refers to a collection of shared meanings held by individuals who distinguish one organization from another. They believed these shared meanings were important characteristics and that the organization's values and the essence of OC could be captured in seven primary characteristics. These are (1) risktaking and innovation; (2) people orientation; (3) attention to detail; (4) outcome orientation; (5) aggressiveness; (6) team orientation; and (7) stability. OC, on the other hand, can be defined by the following characteristics: (1) collective; (2) emotional; (3) historical; (4) symbolic; (5) dynamic; and (6) diffuse (Hammer, 2013).

\subsection{Cameron and Quinn model (CVF)}

Cameron and Quinn proposed and tested CVF to investigate the effect of OC on FP (2011). This was chosen to distinguish between different types of OC. The first reason for selecting CVF is that it contains key components of the four major cultures that underpin FP (Cameron \& Quinn, 2011; Zeb et., 2021). The second reason is that it is also one of the most important and widely used models for constructing the profile of OC (Cameron \& Quinn, 2006; Vilkinas \& Cartan, 2006).

The CVF has two dimensions, represented by two axes, each with a superordinate continuum, as shown in the diagram (Figure 1). The first dimension denotes the flexibility-control axis and describes the two opposing orientations: flexibility (i.e., spontaneity and development) and control (i.e., stability and continuity). The second measurement is the internal-external axis, which also represents two orientations: one centred on support and change within the current organization and the other on adaptation and cooperation within the external environment. As a result, these categories reflect several models for organizational theory, providing a third reason for selecting this model (Cameron \& Quinn, 2006). Furthermore, according to Prajogo and McDermott (2011), the CVF for OC reflects contrasting values in the four organizational cultures, as opposed to other models, such as the OC profile developed by (O'Reilly, 1991), which is another reason for 
selecting this model.

Furthermore, according to Prajogo and McDermott (2011), the CVF for OC reflects contrasting values in the four OC, as opposed to other models, such as the OC profile developed by (O'Reilly, 1991), which is another reason for selecting this model. Furthermore, the central issue of CVF is that organizational effectiveness depends on the organization's ability to meet multiple performance criteria in light of four value sets that involve a mix of two dimensions: flexibility-control and internal-external.

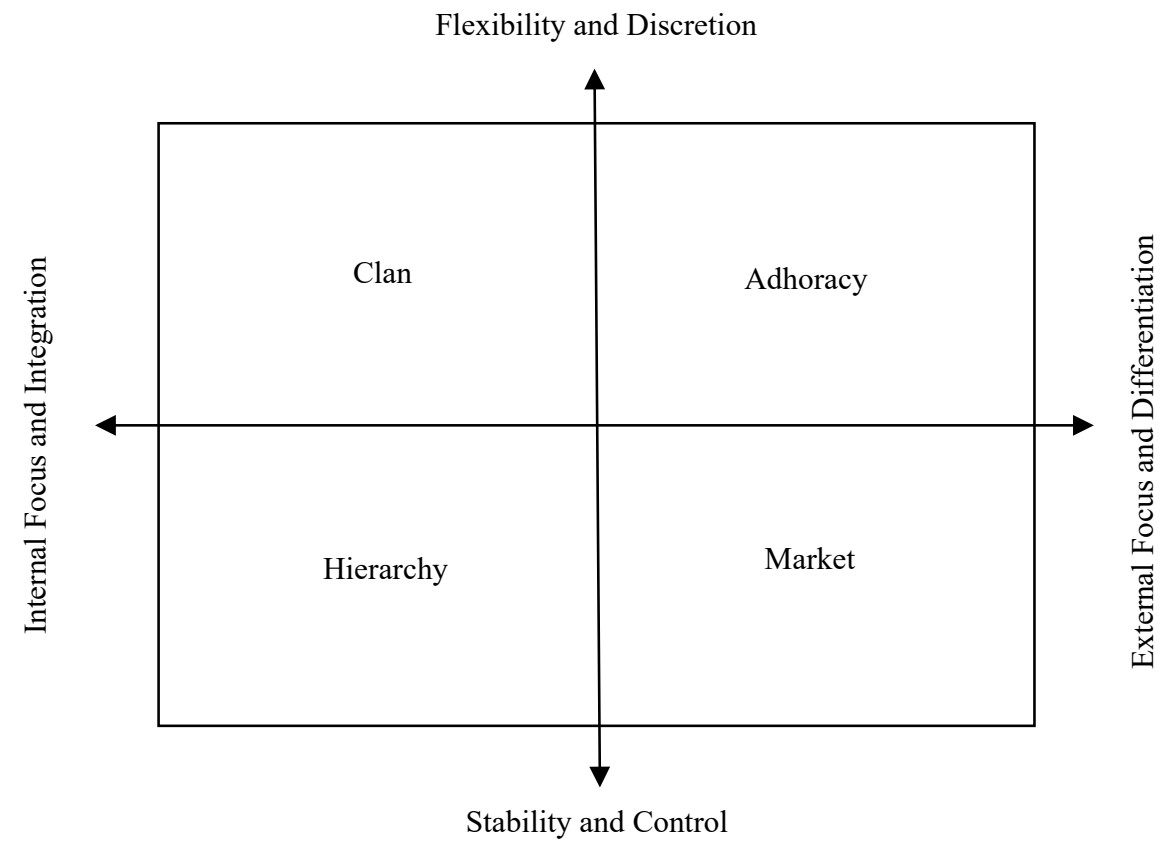

Figure 1. The competing value framework (Cameron \& Quinn, 2011)

Clan culture is in the upper left, adhocracy is in the upper right, hierarchy is in the bottom left, and market culture is in the lower right, as seen in Figure 1. The hierarchy culture is based on a bureaucratic and official procedure emphasizing stability, teamwork, consensus, and tradition. It prioritizes internal rather than external challenges and prioritizes consistency and control over flexibility. A regulated and organized work atmosphere characterizes the hierarchy culture. Techniques direct employees' actions and influential leaders are excellent facilitators and organizers (Cameron \& Quinn, 2011; Aldhuwaihi, 2013; Zeb et al., 2021). This sort of OC is prevalent in large organizations and government offices. The goals of this form of OC are efficiency and simplicity, and the organizational environment is stable and 
K Elnagar, A.,

Abdelkawi, A., Elshaer,

I., \& Salama, S.
The Effect of Organizational Culture on Financial

Performance: Based on Cameron and Quinn Model (CVF)

uncomplicated; changes should be kept to a minimum. In the market culture, the phrase market does not refer to the marketing function; instead, it refers to an organization that acts as a market (Cameron \& Quinn, 2011). It places a premium on consistency and control but emphasizes external factors rather than internal concerns. This culture will likely see the outside world as hostile and look for threats and opportunities to gain a competitive advantage and profit. Its competitive stance and exterior orientation define it. The key values of the market culture are aggression and efficiency (Cameron \& Quinn, 2011; Aldhuwaihi, 2013; Zeb et al., 2021).

Instead of seeking stability and control, the adhocracy culture focuses on external issues and encourages flexibility and carefulness. Originality, inventiveness, risk-taking, and an entrepreneurial mindset characterize adhocracy culture. Organizational charts and formal structures are either undervalued or absent; flexible job positions and established physical space are also evaluated. A self-motivated, enterprising, and creative workplace characterizes the adhocracy culture (Cameron \& Quinn, 2011; Aldhuwaihi, 2013; Zeb et al., 2021). Software development and aerospace companies are two examples of companies dominated by this culture. The main difficulties are creating innovative and unique goods and services while adjusting quickly to new opportunities.

\subsection{Financial performance and organizational culture}

Previous research (Woods, 1989; Koutroumanis, 2005; Gaard et al., 2005) has identified the uniqueness of hospitality culture, but they have been limited to either restaurants or hotels. Woods (1989) was the first researcher to look at the culture of hospitality businesses in the United States. Woods observed and interviewed over 300 restaurant managers and employees and discovered that OC impacts performance. According to several studies, a strong culture is favourably associated with short-term financial performance (Gordon \& DiTomaso, 1992; Denison \& Mishra, 1995). At the same time, Kotter and Heskett (1992) showed that having an "adaptive values" culture can substantially improve long-haul performance relative to short-haul performance.

Theoretical reasons support the assumption that OC is linked to FP and long-term effectiveness (Cameron \& Quinn, 2006; Zheng et al., 2010). According to Zheng et al. (2010), OC is one of the main organizational assets extensively examined concerning organizational effectiveness from a resource-based perspective. Similarly, Peters and Waterman (1982) claimed that $\mathrm{OC}$ is critical in determining an organization's performance. According to Oparanma (2010), OC stimulates or engenders several other actions that 
lead to corporate success. However, regarding the questions surrounding the culture-performance link, Ogbonna and Haris (2000) argue that sufficient evidence exists for the hypothesized association between OC and performance. Scholars have long held that change or transformation can only create long-term growth-oriented performance if the OC and the employees are willing to embrace and relate to the change. For high-performing companies, culture is the most important differentiator (Davidson et al., 2007; Zakari et al., 2013).

Though technological developments are seen as the most important differentiator, OC plays a larger impact in acquiring market share. Technology alone is insufficient; supportive OC must accompany it. According to Kotter and Heskett (1992), culture is one of the most important variables to consider when evaluating an organization's success or failure because cultures can make or break an organization's long-term financial soundness. OC has a considerable direct effect on performance, according to Marcoulides and Heck (1993). According to Oparanma (2010), OC is a significant aspect to consider while evaluating performance. According to Duke II and Edet (2012)'s findings, there is a strong positive relationship between OC and performance.

Some research shows what sorts of OC affect performance outcomes. Through a sample of 327 employees, Davidson et al. (2007) investigated the inter-relationship between OC and financial performance in a South African investment bank. Income statement ratio studies were used to investigate the financial performance connections between cultural characteristics and financial ratios, such as return on investment, return on assets, sales volume, and market share. Consistency, adaptability, learning orientation, empowerment, strategy, and entrepreneurship are the cultural elements that have significantly impacted FP.

Karim (2010) used the Denison model of organizational effectiveness to investigate the impact of OC on the financial performance of Jordan's telecom company Zain. A survey of 50 employees was conducted to gather information on the various dimensions of OC. The data analysis revealed that OC has a positive impact on the company's financial results as well as other effectiveness indices. Zain Telecom has surpassed its key competitor, Jordan Telecom, in all financial dimensions: product development, market share, profitability ratio, liquidity, and investment ratio. Ogbonna and Haris (2000) state that competitive and inventive cultures are linked to improved performance.

Based on previous research findings, we will test the following four hypotheses: 
K Elnagar, A., Abdelkawi, A., Elshaer, I., \& Salama, S.
The Effect of Organizational Culture on Financial

Performance: Based on Cameron and Quinn Model (CVF)

$\mathbf{H}_{01}$ : There is a statistically significant correlation between OC based on Cameron and Quinn Model (CVF) and FP.

$\mathbf{H}_{\mathbf{0 2}}$ : There is a positive effect of OC based on the Cameron and Quinn Model (CVF) on FP.

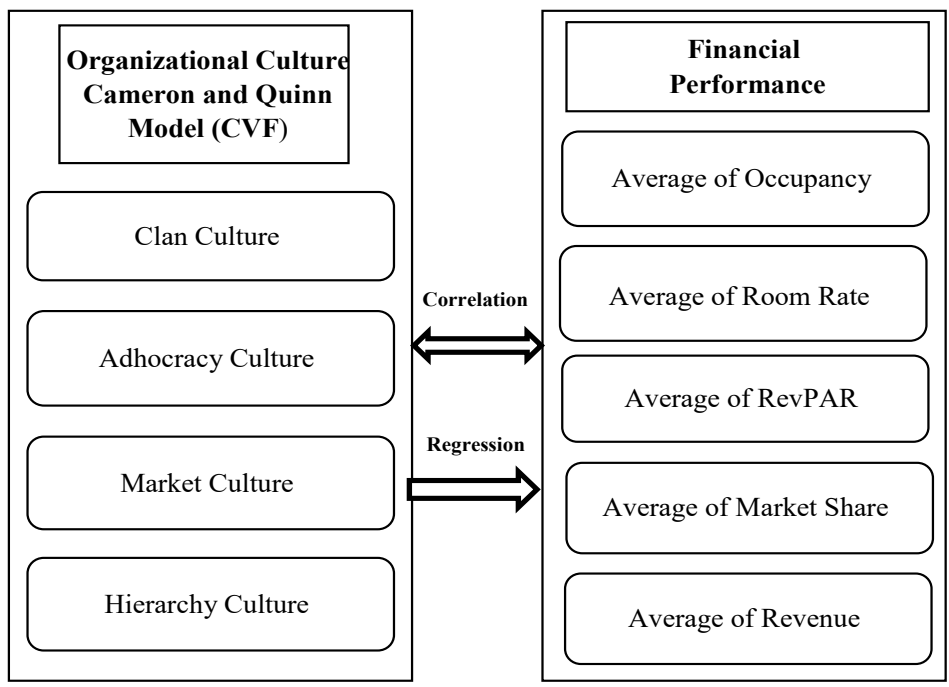

Figure 2. A theoretical framework based on previous studies

\section{Research methodology}

The research relied on three approaches: (1) descriptive approach in the reference review; (2) analytical approach in the field research; (3) explanatory approach in interpreting statistical data and clarifying the different relationships between the research variables. The research used a questionnaire to collect field data, and it was divided into three parts according to the five-point Likert scale.

The first part included the demographic data of the study sample. The second part included OC types (clan culture, adhocracy culture, market culture, hierarchy culture) based on Cameron and Quinn model (CVF), whose questions were drawn from studies (Cameron \& Quinn, 2006; 2011). The third included FP (occupancy percentage, average of room rate, RevPAR, market share, revenue) that relied on the scale used by (Himmer, 2013).

Data was obtained from surveying 416 general, executive, HR, and quality managers working in four five-star hotels in Sharm El Sheikh city 104 hotel in Egypt. A total of 296 responses (160 from four-star hotels and 136 from five-star hotels) yield a response rate of $72 \%$, as shown in Table 1 . 
Table 1. The response rate in the research sample

\begin{tabular}{|c|c|c|}
\hline & \multicolumn{2}{|c|}{$\begin{array}{l}\text { General managers, Executive managers, HR managers, } \\
\text { and quality managers }\end{array}$} \\
\hline & Four-star hotels & Five-star hotels \\
\hline Questionnaires delivered & 244 & 172 \\
\hline Questionnaires returned & 160 & 136 \\
\hline Partially responded & 50 & 25 \\
\hline Opted out & 34 & 11 \\
\hline Response rate & (296/416) $72 \%$ & \\
\hline
\end{tabular}

SPSS V25 was used to examine the data, and statistical procedures such as reliability analysis, descriptive analysis, multiple linear regression, and correlation were applied.

\subsection{Reliability and validity test of research scale}

Cronbach's Alpha correlation coefficient test was used to validate the reliability and validity of both OC types and FP, as indicated in table 2 .

Table 2. Reliability and validity results

\begin{tabular}{|c|c|c|c|c|}
\hline Variable & Dimensions & Items No & Cronbach's alpha & Validity \\
\hline \multirow{5}{*}{$\begin{array}{l}\text { Organizational } \\
\text { culture }\end{array}$} & & & 0.954 & \multirow{5}{*}{0.977} \\
\hline & Clan culture & 6 & 0.853 & \\
\hline & Adhocracy culture & 6 & 0.916 & \\
\hline & Market culture & 6 & 0.900 & \\
\hline & Hierarchy culture & 6 & 0.903 & \\
\hline \multirow{6}{*}{$\begin{array}{l}\text { Financial } \\
\text { performance }\end{array}$} & & & 0.953 & \multirow{6}{*}{0.976} \\
\hline & Average of occupancy & 1 & 0.886 & \\
\hline & Average room rate & 1 & 0.879 & \\
\hline & Average RevPAR & 1 & 0.840 & \\
\hline & Average market share & 1 & 0.869 & \\
\hline & Average of revenue & 1 & 0.868 & \\
\hline Total scale & & & 0.952 & 0.975 \\
\hline
\end{tabular}

Table 2 shows the Cronbach Alpha value, reflecting the two variables' excellent internal consistency. Each item has a dependability score of 0.952 . In contrast, construct OC has a score of 0.954 , and construct FP has a score of 0.953 , which are higher than the recommended cut-off level of 0.7 . Furthermore, the validity of the two constructs is 0.977 and 0.976 , respectively. This indicates that the research scale can be trusted. 


\section{K Elnagar, A., Abdelkawi, A., Elshaer, I., \& Salama, S.}

The Effect of Organizational Culture on Financial

Performance: Based on Cameron and Quinn Model (CVF)

\subsection{Research sample opinion about OC types and FP}

This section aims to learn about the research sample's thoughts on OC kinds, FP, and the extent to which hotels adopt these types, and to verify this, a descriptive analysis test was conducted, as shown in Table 3.

Table 3. Descriptive analysis for OC types

\begin{tabular}{|c|c|c|}
\hline Dimensions/Items & Mean & $\begin{array}{l}\text { Std. } \\
\text { deviation }\end{array}$ \\
\hline Clan culture & 4.19 & 0.612 \\
\hline $\begin{array}{l}\text { Our hotel has a very intimate setting, like having a second family. People } \\
\text { reveal a lot about themselves. }\end{array}$ & 4.08 & 0.603 \\
\hline $\begin{array}{l}\text { Mentoring, facilitation, and nurturing are all qualities that our hotel's } \\
\text { leadership exemplifies. }\end{array}$ & 4.14 & 0.647 \\
\hline $\begin{array}{l}\text { Collaboration, consensus, and participation distinguish our hotel's } \\
\text { management approach. }\end{array}$ & 4.19 & 0.779 \\
\hline $\begin{array}{l}\text { Loyalty and mutual trust are the glue that ties our hotel together. This } \\
\text { organization has many people that are passionate about it. }\end{array}$ & 4.31 & 0.784 \\
\hline $\begin{array}{l}\text { Our hotel places a strong emphasis on personal growth. High levels of trust, } \\
\text { openness, and participation continue to exist. }\end{array}$ & 4.25 & 0.867 \\
\hline $\begin{array}{l}\text { Our hotel measures its success in human resource development, teamwork, } \\
\text { staff commitment, and concern for people. }\end{array}$ & 4.16 & 0.964 \\
\hline Adhocracy culture & 4.10 & 0.709 \\
\hline $\begin{array}{l}\text { Our hotel is a fast-paced, entrepreneurial environment. Individuals are } \\
\text { willing to take chances and put their necks out there. }\end{array}$ & 4.04 & 0.682 \\
\hline $\begin{array}{l}\text { Our hotel's leadership is widely regarded as exemplifying entrepreneurship, } \\
\text { creativity, and risk-taking. }\end{array}$ & 4.14 & 0.733 \\
\hline $\begin{array}{l}\text { Individual risk-taking, innovation, flexibility, and individuality characterize } \\
\text { our hotel's management approach. }\end{array}$ & 4.15 & 0.908 \\
\hline $\begin{array}{l}\text { A commitment to innovation and development is the glue that keeps our } \\
\text { hotel together. The importance of being on the cutting edge is emphasized. }\end{array}$ & 4.17 & 0.910 \\
\hline $\begin{array}{l}\text { Our hotel strongly emphasizes obtaining new resources and posing new } \\
\text { difficulties. Trying new things and looking for new chances are highly } \\
\text { regarded. }\end{array}$ & 4.05 & 0.924 \\
\hline $\begin{array}{l}\text { Our hotel considers itself self-successful if it has the most unique or cutting- } \\
\text { edge products. It is a product inventor and leader. }\end{array}$ & 4.04 & 0.994 \\
\hline - I t & 4.16 & 0.701 \\
\hline $\begin{array}{l}\text { Our hotel is particularly focused on achieving its objectives. Getting the task } \\
\text { done is a huge problem. People are very competitive and goal-oriented. }\end{array}$ & 4.04 & 0.793 \\
\hline $\begin{array}{l}\text { Our hotel's leadership is well regarded as exemplifying a no-nonsense, } \\
\text { aggressive, results-oriented approach. }\end{array}$ & 4.18 & 0.773 \\
\hline $\begin{array}{l}\text { Our hotel's management style reflects hard-driving competitiveness, high } \\
\text { demands, and achievement. }\end{array}$ & 4.16 & 0.802 \\
\hline $\begin{array}{l}\text { The emphasis on achievement and goal achievement is the glue that keeps } \\
\text { our hotel together. }\end{array}$ & 4.22 & 0.908 \\
\hline $\begin{array}{l}\text { Our hotel places a premium on achievement and competitive acts. It is all } \\
\text { about hitting stretch goals and winning in the marketplace. }\end{array}$ & 4.15 & 0.890 \\
\hline $\begin{array}{l}\text { Our hotel defines success as outperforming the competition and succeeding } \\
\text { in the marketplace. The ability to lead in a competitive market is crucial. }\end{array}$ & 4.18 & 0.965 \\
\hline
\end{tabular}




\begin{tabular}{|c|c|c|}
\hline Dimensions/Items & Mean & $\begin{array}{l}\text { Std. } \\
\text { deviation }\end{array}$ \\
\hline Hierarchy culture & 4.00 & 0.797 \\
\hline $\begin{array}{l}\text { Our hotel is a very structured and supervised environment. What people do } \\
\text { is often governed by formal procedures. }\end{array}$ & 4.08 & 0.781 \\
\hline $\begin{array}{l}\text { Our hotel's leadership is widely regarded as exemplifying coordinating, } \\
\text { organizing, or smooth-running efficiency. }\end{array}$ & 4.11 & 0.899 \\
\hline $\begin{array}{l}\text { Our hotel's management style is characterized by job security, conformity, } \\
\text { predictability, and relationship stability. }\end{array}$ & 3.92 & 0.907 \\
\hline $\begin{array}{l}\text { Formal regulations and policies are the glue that ties our hotel together. It is } \\
\text { critical to keep a hotel running smoothly. }\end{array}$ & 3.96 & 0.958 \\
\hline $\begin{array}{l}\text { Our hotel places a premium on consistency and longevity. The importance } \\
\text { of efficiency, control, and seamless operations cannot be overstated. }\end{array}$ & 3.95 & 1.030 \\
\hline $\begin{array}{l}\text { Efficiency is the cornerstone of our hotel's success. The importance of on- } \\
\text { time delivery, flexible scheduling, and low-cost production cannot be } \\
\text { overstated. }\end{array}$ & 4.00 & 1.100 \\
\hline
\end{tabular}

Table 3 reveals that most of the study sample agreed that the surveyed hotels adopted all OC kinds. OC types (clan culture, adhocracy culture, market culture, hierarchy culture) had mean values ranging from 4.00 to 4.19 . According to the mean values, most OC types in hotels reflect clan culture, followed by market culture, adhocracy culture, and hierarchical culture. The standard deviations for all variables range from 0.612 to 0.797 . This shows that the data follows a normal distribution and does not cluster too closely around the mean but instead drifts away and deviates significantly. Simoneaux and Stroud (2014) mentioned that OC is a collection of cultures containing behaviour patterns, beliefs, values, and work styles that form the firm's identity, distinguish it from others, and improve performance. Employees in a strong OC share similar perspectives on the organization and act in accordance with organizational values. Because culture engages and motivates employees, business managers must demonstrate strong OC to influence their employees' work attitude and performance.

Table 4. Descriptive analysis for FP

\begin{tabular}{lll}
\hline Dimensions & Mean & Std. deviation \\
\hline Average of occupancy & 3.80 & 0.645 \\
Average room rate & 3.79 & 0.840 \\
Average RevPAR & 3.79 & 0.624 \\
Average market share & 3.81 & 0.722 \\
Average of revenue & 3.78 & 0.637 \\
Total mean & 3.80 & 0.902 \\
\hline
\end{tabular}

Table 4 shows that the mean values of FP (average occupancy, average room rate, average RevPAR, average market share, average revenue) 


\section{K Elnagar, A., Abdelkawi, A., Elshaer, I., \& Salama, S.}

The Effect of Organizational Culture on Financial Performance: Based on Cameron and Quinn Model (CVF)

ranged from 3.78 to 3.81 . Most FP dimensions in hotels, according to the mean values, reflect average market share, average occupancy, average room rate, average RevPAR, and lastly, average revenue. The standard deviations for all variables range from 0.624 to 0.902 . This shows that the data follows a normal distribution and does not cluster too closely around the mean but instead drifts away and deviates significantly.

\subsection{Research hypotheses test} and FP.

$\mathbf{H}_{01}$ : There is a statistically significant correlation between OC types

The Pearson correlation coefficient was employed to establish the nature of the link between the study variables, as given in table 5, to test the validity of this hypothesis.

Table 5. Correlation matrix among variables (Pearson's R correlation)

\begin{tabular}{llllll}
\hline Variables & Clan culture & Adhocracy culture & Market culture & Hierarchy culture & FP \\
\hline Clan culture & 1 & & & & \\
Adhocracy culture & 0.813 & 1 & & & \\
Market culture & 0.820 & 0.878 & 1 & 1 & \\
Hierarchy culture & 0.814 & 0.888 & 0.853 & 0.641 & 1 \\
FP & 0.622 & 0.667 & 0.648 & & \\
\hline
\end{tabular}

All Correlations are significant at the 0.01 level.

Table 5 reveals a statistically significant link between OC types (clan culture, adhocracy culture, market culture, hierarchy culture) and FP, with correlation coefficient values ranging from 0.641 to 0.888 . Theoretical reasons support the assumption that $\mathrm{OC}$ is linked to FP and long-term effectiveness (Cameron \& Quinn, 2006; Zheng et al., 2010). As a result, the first hypothesis (there is a statistically significant correlation between OC types and FP) is accepted.

$\mathbf{H}_{\mathbf{0 2}}$ : There is a positive effect of OC types on FP.

Multiple linear regression was used to demonstrate the potential impact of OC types (clan culture, adhocracy culture, market culture, hierarchy culture) on FP in surveyed hotels, as shown in Table 6. 
Table 6. The effect of OC types on FP

\begin{tabular}{lllllll}
\hline & & \multicolumn{2}{c}{ FP } & \\
& $\beta$ & $\mathrm{T}$ & Sig. & $\mathrm{F}$ & Sig. & $\mathrm{R}^{2}$ \\
\hline Clan culture & 0.195 & 4.24 & 0.000 & 341.49 & 0.000 & 0.824 \\
Adhocracy culture & 0.509 & 9.11 & 0.000 & & & \\
Market culture & 0.224 & 4.01 & 0.000 & & & \\
Hierarchy culture & 0.148 & 4.39 & 0.000 & & & \\
\hline
\end{tabular}

Table 6 shows a positive regression of OC types (clan culture, adhocracy culture, market culture, hierarchy culture) on FP. According to the regression value, the order of dimensions is as follows:

- Adhocracy culture positively affects FP, with a regression value of ( $\beta$ $=0.509$ ) and $\mathrm{T}=9.11$, where the $\mathrm{T}$ value is significant if it is $\leq 2$ at level Sig. $\mathrm{P}<0.01$, and this kind is considered the most effective type of FP.

- Market culture positively affects FP, with a regression value of $(\beta=$ 0.224 ) and $T=4.01$, where the $T$ value is significant if it is $\leq 2$ at level Sig. $\mathrm{P}<0.01$, and this kind is considered the second effective type of FP.

- Clan culture positively affects FP, with a regression value of $(\beta=$ 0.195 ) and $T=4.24$, where the $T$ value is significant if it is $\leq 2$ at level Sig. $\mathrm{P}<0.01$, and this kind is considered the third effective type of FP.

- Hierarchy culture positively affects FP, with a regression value of ( $\beta$ $=0.148$ ) and $\mathrm{T}=4.39$, where the $\mathrm{T}$ value is significant if it is $\leq 2$ at level Sig. $\mathrm{P}<0.01$, and his kind is considered the fourth most effective type on FP.

Also, table 6 shows that the $F$ value is 314.49 , and the significance of the model was confirmed at the level of significance $(\mathrm{P}<0.01$, and the $\mathrm{R} 2$ model is $82.4 \%$ ). OC kinds are favourable to performance, according to several studies on the culture-performance link. Some of these studies looked at the impact of OC on FP (Xenikou \& Simosi, 2006), productivity and quality (Mathew, 2007), profitability, and marketing (Tseng, 2010). (Uzkurt et al., 2013). As a result, the second hypothesis (there is a positive effect of OC types on FP) is accepted.

\section{Conclusions and recommendations}

This study aimed to investigate the effect of OC on FP in the Egyptian hotel business using the Cameron and Quinn Model (CVF). The study's 
K Elnagar, A., Abdelkawi, A., Elshaer, I., \& Salama, S.
The Effect of Organizational Culture on Financial

Performance: Based on Cameron and Quinn Model (CVF)

empirical findings revealed that Egyptian hotels use OC types extensively; the association between $\mathrm{OC}$ types and FP is positive, and the influence of OC types on FP is positive.

In light of these findings, the research suggests that hotels in Egypt pay close attention to consolidating OC types. They enhance FP positively, promoting organizational values such as fairness, equality, teamwork, and employee cooperation. In addition, it contributes to increasing interest in organizational beliefs such as the human element, job satisfaction, and increased rewards and incentives.

\section{Acknowledgements}

The authors would like to express their gratitude to the Editor in Chief and anonymous referees, whose insightful remarks considerably improved the paper's quality.

\section{Declaration of conflicting interests}

The author(s) declared no potential conflicts of interest with respect to the research, authorship, and/or publication of this article.

\section{References}

Abu-Jarad, I. Y., Yusof, N., \& Nikbin, D. (2010). A review paper on organizational culture and organizational performance. Int. J. Bus. Soc. Sci, 1(3), 26-46.

Alvesson, M., \& Sveningsson, S. (2008). Changing organizational culture: Cultural change work in progress. Routledge, New York. https://doi.org/10.4324/9780203935965

Brown, A. D. (1998). Organizational Culture. Financial Times.

Cameron, K. S. \& Quinn, R.E. (2006). Diagnosing and changing organizational culture: based on the competing values framework. Jossey-Bass and San Francisco.

Cameron, K. S. \& Quinn, R.E. (2011). Diagnosing and changing organizational culture: based on the competing values framework. John Wiley and Sons.

Cunliffe, A. L. (2008). Organization theory. London: Sage Publications.

Davidson, G., Coetzee, M. \& Visser, D. (2007). Organizational culture and financial performance in a South African investment bank. SA J. Ind. Psychol, 33(1), 38-48. https://doi.org/10.4102/sajip.v33i1.261

Deal, T. E., \& Kennedy, A.A. (1982). Corporate cultures. Reading. MA. Addison-Wesley.

Denison, D.R. and Mishra, A.K. (1995). Toward a theory of organizational culture and effectiveness. Organization Science, 6(2), 204-223.

Derbali, A., \& Elnagar, A. K. (2020). Measuring Student and Staff Satisfaction with the University Facilities. Virtual https://doi.org/10.34021/ve.2020.03.03(2)

Economics, 3(3),

$25-52$.

Duke II, J., \& Edet, G.H. (2012). Organizational culture as a determinant of nongovernmental organization performance: Primer evidence from Nigeria. Int. Bus. Manag, 4(1), 66-75. 
Elnagar, A. K., \& Derbali, A. (2020). The importance of tourism contributions in Egyptian economy. International Journal of Hospitality and Tourism Studies (IJHTS), 1(1), 45-52. https://doi.org/10.31559/IJHTS2020.1.1.5

Elnagar, A.K., \& Sayed, M. (2021). Investigating the relationship between humble leadership behavior and job alienation of employees in Egyptian hotels, JAAUTH, 20(3), 311329. https://doi.org/10.21608/jaauth.2021.65801.1145

Fekete, H. \& Bocskei, E. (2011). Cultural waves in company performance. Res. J. Econ. Bus, $3,38-40$.

Gordon, G.G., \& DiTomaso, N. (1992). Predicting corporate performance from organizational culture. Journal of Management Studies, 29, 783-798. https://doi.org/10.1111/j.1467-6486.1992.tb00689.x

Himmer, N. S. (2013). How does organizational culture influence the performance of luxury hotels based on the example of the Ritz-Carlton hotel company L.L.C? (Unpublished Master dissertation). Modulvienna University. The UK. ProQuest Dissertations and Theses.

Hofstede, G., Neuijen, B., Ohayv, D.D., \& Sanders, G. (1990). Measuring organizational cultures: A qualitative and quantitative study across twenty cases. Adm. Sci. Q, 35 (2), 286. https://doi.org/10.2307/2393392

Karim, M. (2010). Relationship between corporate culture and organizational effectiveness: a case study on Zain telecommunication limited.

Kotter, J. P., \& Heskett, J.L. (1992). Corporate culture and performance. London: Free Press.

Koutroumanis, D. A. (2005). Behavioral intentions in the full-service restaurant industry: The effect service quality and organizational culture have on customers' intentions to return. (Unpublished Doctoral dissertation). ProQuest Dissertations and Theses.

Marcoulides, G. A. \& Heck, R. H. (1993). Organizational culture and performance: proposing and testing a Model. Organ. Sci, 4, 209-225. https://doi.org/10.1287/orsc.4.2.209

Mathew, J. (2007). The relationship of organizational culture with productivity and quality: A study of Indian software organizations. Empl. Relat, 29 (6), 677-695.

Nikpour, A. (2017). The impact of organizational culture on organizational performance: The mediating role of employee's organizational commitment. International Journal of Organizational Leadership, 6 (1), 62-75. https://doi.org/10.33844/ijol.2017.60432

Øgaard, T., Larsen, S., \& Marnburg, E. (2005). Organizational culture and performanceevidence from the fast-food restaurant industry. Food Serv. Technol, 5 (1), 23-34. https://doi.org/10.1111/j.1471-5740.2005.00109.x

Ogbonna, E., \& Harris, L. (2000). Leadership Style, organizational culture, and performance: empirical evidence from UK companies. International Journal of Human Resources Management, 11(4), 766-788. https://doi.org/10.1080/09585190050075114

Oparanma, A.O. (2010). The Organizational culture and corporate performance in Nigeria. International Journal of African Studies, 3, 34-40.

Robbins, S.P. (2005). Organizational behavior: concepts, controversies, and applications. Prentice-Hall.

Schein, E.H. (1990). Organizational culture. American Psychologist. 45(2), 109-119. https://doi.org/10.1037/0003-066X.45.2.109

Simoneaux, S. \& Stroud, C. (2014). A strong corporate culture is a key to success. Journal of Pension Benefits. 22(1), 51-53.

Tseng, S. (2010). The correlation between organizational culture and knowledge conversion on corporate performance. J. Knowl. Manag, 14(2), 269-284. 
K Elnagar, A.,

Abdelkawi, A., Elshaer, I., \& Salama, S.
The Effect of Organizational Culture on Financial

Performance: Based on Cameron and Quinn Model (CVF)

https://doi.org/10.1108/13673271011032409

Uzkurt, C., Kumar, R. SemihKimzan, H., \& Eminoğlu, G. (2013). Role of innovation in the relationship between organizational culture and firm performance: A study of the banking sector in Turkey. Eur. J. Innov. Manag, 16(1), 92-117. https://doi.org/10.1108/14601061311292878

Woods, R. H., (1989). More alike than different: The culture of the restaurant industry. Cornell Hotel and Restaurant Administration Quarterly, 30(2), 82-97. https://doi.org/10.1177/001088048903000219

Xenikou, A. \& Simosi, M. (2006). Organizational culture and transformational leadership as predictors of business unit performance. J. Manag. Psychol, 21(6), 566-579. https://doi.org/10.1108/02683940610684409

Zakari, M., Poku, K. \& Owusu-Ansah, W. (2013). Organizational culture and organizational performance: empirical evidence from the banking industry in Ghana. International Journal of Business, Humanities, and Technology, 3(1), 95-107.

Zeb, A., Akbar, F., Hussain, K., Safi, A., \& Zeb, F. (2021). The competing value framework model of organizational culture, innovation and performance, Business Process Management Journal, 27 (2), 658-683. https://doi.org/10.1108/BPMJ-11-20190464

Zheng, W., Yang, B., \& McLean, G.N. (2010). Linking organizational culture, structure, strategy, and organizational effectiveness: Mediating role of knowledge management. J. Bus. Res, 63(7), 763-771. https://doi.org/10.1016/j.jbusres.2009.06.005 